\title{
RUMUSAN PENGATURAN CREDIT CARD FRAUD DALAM HUKUM PIDANA INDONESIA DITINJAU DARI ASAS LEGALITAS
}

\author{
Said Noor Prasetyo \\ Fakultas Hukum Universitas Muhammadiyah Malang \\ Jl. Raya Tlogomas No. 246 Malang \\ said.n.prasetyo@gmail.com/saidnoor@umm.ac.id
}

\begin{abstract}
Internet is an information technology development product. Internet provide so many benefits for society in various field of life. One of its benefit is electronic payment system in e-commerce system. That benefits are also used by irresponsible persons for te crimes. One form ofcrimes in these field was credit card fraud. Based on data, Indonesia is a country with te highest rate of credit card fraud around the world. This is caused by the weakness of legal substance that regulate such crime. The Purpose of this research is to looking for such weakness based on principles of legality point of view. For such purpose, researcher use normative juridical of research methods with the konseptual and statute approach.
\end{abstract}

\section{Keywords: Internet, E-Commerce, Credit Card Fraud, Legal Subtance}

\begin{abstract}
Abstraksi
Internet merupakan produk perkembangan teknologi informasi. Internet dapat memberikan manfaat yang sangat besar bagi masyarakat di berbagai bidang kehidupan. Salah satu manfaat tersebut adalah adanya sistem pembayaran elektronik dalam sistem perdagangan elektronik (e-commerce). Besarnya manfaat teknologi tersebut juga dimanfaatkan oleh oknum yang tidak bertanggung jawab untuk melakukan kejahatan. Salah satu bentuk kejahatan dalam bidang tersebut adalah credit card fraud. Berdasar pada data, Indonesia merupakan Negara dengan tingkat kejahatan credit card fraud tertinggi di dunia. Hal ini disebabkan oleh lemahnya substansi hukum yang mengatur kejahatan tersebut. Tujuan dari penelitian ini adalah untuk melihat kelemahan tersebut jika ditinjau dari asas legalitas. Untuk tujuan itu, penulis menggunakan metode penelitian yuridis normatif dengan pendekatan konseptual dan peraturan perundang-undangan.
\end{abstract}

\section{Kata Kunci: Internet, Perdagangan Elektronik, Credit Card Fraud, Substansi Hukum}

\section{A. Pendahuluan}

Perpaduan telekomunikasi dan komputer melahirkan internet yang menjadi tulang punggung teknologi informasi. ${ }^{1}$ Internet (interconection network) merupakan jaringan yang menghubungkan beberapa jaringan komputer (network of network). internet memungkinkan jaringan komputer untuk berkomunikasi satu sama lain dan menciptakan sistem informasi

1 Agus Raharjo, Cybercrime: Pemahaman dan Upaya Pencegahan Kejahatan Berteknologi, Citra Aditya Bakti, Bandung, 2002, hlm 2-3; Sutan Remy Syahdeini, Kejahatan dan Tindak Pidana Komputer, Grafiti, Jakarta, 2009, hlm 1 
global berbasis komputer. internet memungkinkan bagi setiap orang yang menggunakan perangkat IT untuk mendapatkan informasi di ujung jari mereka. ${ }^{2}$

Jaringan internet baru digunakan di Indonesia sekitar dua dekade terakhir. Meskipun begitu, internet sangat cepat menyebar di hampir semua wilayah Indonesia. Berdasarkan survei yang diselenggarakan Asosiasi Penyelenggara Jasa Internet Indonesia (APJII) diperoleh data jumlah pengguna internet di Indonesia tahun 2012 mencapai 63 juta orang atau 24,23 persen dari total populasi negara ini. Pada tahun 2013, angka itu diprediksi naik sekitar 30 persen menjadi 82 juta pengguna dan terus tumbuh menjadi 107 juta pada 2014 dan 139 juta atau 50 persen total populasi pada $2015 .^{3}$ Lebih besar dari pada itu, dari laporan Asosiasi Penyelenggara Jasa Internet Indonesia (APJII) dan pernyataan dari beberapa praktisi internet, bukan tidak mungkin jika pengguna internet di Indonesia sekarang sudah mencapai atau melebihi angka 120 juta orang.

Teknologi informasi (information technology) memegang peranan penting dalam kehidupan manusia. Teknologi informasi diyakini membawa keuntungan dan kepentingan yang besar bagi negara-negara di dunia, termasuk di Indonesia. Setidaknya ada 2 (dua) hal yang membuat teknologi informasi dianggap begitu penting dalam memacu pertumbuhan ekonomi dunia. Pertama, teknologi informasi mendorong permintaan atas produk-produk teknologi informasi itu sendiri, seperti komputer, modem, sarana untuk membangun jaringan internet dan sebagainya. Kedua, adalah memudahkan transaksi bisnis terutama bisnis keuangan di samping bisnis-bisnis umum lainnya. ${ }^{4}$ Kehadiran internet ini memberikan manfaat yang begitu besar untuk memberikan kemudahan kepada setiap orang dalam menjalankan setiap kegiatannya khususnya dalam bidang ekonomi perdagangan.

Bidang perdagangan merupakan tulang punggung perekonomian suatu negara. Tingginya volume perdagangan merupakan indikasi utama tingginya perekonomian sebuah negara. Untuk itulah setiap negara berlomba-lomba meningkatkan volume perdagangan mereka melalui berbagai macam cara. Salah satu cara yang paling banyak digunakan adalah dengan memanfaatkan perkembangan teknologi informasi. Dengan memanfaatkan teknologi informasi yang disebut jaringan internet, para pelaku bisnis perdagangan dapat lebih mudah dalam melakukan aktivitas perdagangannya baik dalam hal perluasan pasar maupun dalam hal efisiensi perdagangan. Penggunaan jaringan internet dalam sistem perdagangan ini biasa disebut dengan electronic commerce (e-Commerce) $)^{5}$.

Dorongan utama lahirnya e-commerce, selain disebabkan oleh adanya perkembangan teknologi informasi, adalah adanya tuntutan masyarakat akan terciptanya pelayanan yang serba cepat, mudah dan praktis. Perdagangan elektronik ini memberikan manfaat yang sangat

McQuade, Samuel C., Encyclopedia of Cybercrime, London, Greenwood Press, 2009, hlm 100

Oik Yusuf, 2013, Pengguna Internet Indonesia Bisa Tembus 82 Juta, 2012, <http://tekno. kompas.com/read/2012/12/13/10103065/2013.pengguna.internet.indonesia.bisa.tembus.82.juta> [05/11/2013]

4 Agus Rahardjo, Op Cit, hlm 1

5 Dikdik M. Arief Mansur dan Elisatris Gultom, Cyber Law: Aspek Hukum Teknologi Informasi, Refika Aditama, Bandung, 2005, hlm 144 
besar kepada setiap pihak yang terlibat dalam perdagangan, baik kepada perusahan penyedia barang dan jasa, konsumen, maupun masyarakat umum. Perdagangan elektronik tidak hanya membuka pasar baru bagi produk dan/ atau jasa yang ditawarkan mencapai konsumen baru, tetapi ia juga dapat mempermudah cara perusahaan melakukan bisnis. ${ }^{6}$ Produsen dan distributor lebih bebas, mudah dan cepat dalam menawarkan dan memasarkan produk barang dan/ atau jasa yang mereka hasilkan kepada konsumen dalam jangkauan yang jauh lebih luas. Begitu pula dengan konsumen dengan bebas, mudah dan cepat memilih dan membandingkan produk yang mereka inginkan.

Percepatan perdagangan ini tidak dapat dilepaskan dari perkembangan dunia perbankan. Perkembangan teknologi informasi di bidang perbankan mendorong aktivitas perdagangan elektonik semakin mudah, cepat, praktis, efektif dan efisien. Dengan perkembangan teknologi informasi, dunia perbankan menciptakan sarana/ metode pembayaran elektronik yang jauh berbeda dengan metode pembayaran tradisional. Perbedaan mendasar di antara sistem pembayaran elektronik dan sistem pembayaran tradisional hanyalah terdigitalnya data-data untuk sistem pembayaran elektronik. ${ }^{7}$ Dengan perkembangan ini, Sistem pembayaran tidak hanya terbatas pada sistem pembayaran berbasis uang kartal, melainkan juga berbasis pada data-data keuangan seseorang baik berupa debit maupun kredit.

Terdapat beberapa jenis alat pembayaran elektronik yang disediakan oleh dunia perbankan, termasuk juga penyedia jasa keuangan. Diantara beberapa jenis alat pembayaran tersebut yang paling populer digunakan bertransaksi di Indonesia adalah Kartu Debit atau biasa dikenal dengan sebutan Kartu ATM dan juga Kartu Kredit. Diantara dua jenis alat pembayaran elektronik tersebut, Kartu Debit/ATM merupakan Kartu pembayaran yang saat ini paling diminati oleh masyarakat Indonesia dalam melakukan transaksi keuangan. Selama tahun 2010, dengan jumlah kartu yang beredar sebesar 51,6 juta kartu, volume penggunaan kartu ATM/debit yang mencapai 1,81 milyar transaksi atau 4,95 juta transaksi per hari, menjadi yang paling tinggi diantara alat pembayaran lainnya. ${ }^{8}$

Kartu kredit memang bukan merupakan alat pembayaran yang paling diminati di Indonesia. Meskipun begitu, bukan berarti jumlah masyarakat pengguna kartu kredit di Indonesia hanyalah sedikit. Bank Indonesia (BI) mencatat jumlah pemegang kartu kredit telah mencapai 14.591.371 di Januari 2013. Rata-rata setiap orang memegang 3 kartu kredit. Adapun nilai transaksinya mencapai Rp 17,96 triliun di awal tahun 2013 ini. ${ }^{9}$ Berdasarkan data Asosiasi Kartu Kredit Indonesia, jumlah kartu kredit pada bulan Juni 2011 sebesar 126,47 juta dengan jumlah transaksi 152,31 kali. Sementara nilai transaksi Rp131,494 triliun. Sementara untuk keseluruhan tahun 2010, jumlah kartu mencapai 154,25 juta dengan

6 Adi Nugroho, e-commerce: Memahami Perdagangan Modern di Dunia Maya, Informatika, Bandung, 2006, hlm 19

Ibid, hlm 79

8 Bank Indonesia, (tanpa Tahun) "Alat Pembayaran: Kartu ATM/Debet", <http://www. bi.go.id/web/id/Info+dan+Edukasi+Konsumen/ Alat+Pembayaran/> [21/09/2013]

9 Herdaru Purnomo, 2013, "Jumlah Pemegang Kartu Kredit Tembus 14 Juta, Satu Orang Punya 3 Kartu", <http://finance.detik.com/read/2013/ 03/04/133250/2184937/5/jumlah-pemegang-kartu-kredit-tembus-14juta-satu-orang-punya-3-kartu> [24/09/2013] 
transaksi sebanyak 194,67 kali. Nilai transaksi 2010 sebesar Rp 158,68 triliun. Pada 2009 jumlah kartu kredit sebanyak 142,49 juta dengan jumlah transaksi 177,81 kali. Sementara nilai transaksi Rp 132,65 triliun. ${ }^{10}$ Meskipun jumlah pengguna kartu kredit tidak sebanyak pengguna kartu ATM/ debet, akan tetapi nilai transaksi dengan menggunakan kartu kredit sangat tinggi, jauh melebihi jumlah transaksi dengan menggunakan kartu ATM/ debet.

Dengan melihat data sebagaimana diuraikan di atas, maka dengan memanfaatkan perkembangan teknologi informasi tersebut, sebenarnya Indonesia memiliki potensi yang sangat besar untuk mengembangkan perekonomian negara. Pemerintah dapat mendorong masyarakat lebih kreatif memanfaatkan teknologi di bidang informasi untuk melakukan pengembangan usaha perdagangan. Dengan dorongan pemerintah tersebut masyarakat dapat lebih termotivasi untuk menjadi pengusaha-pengusaha baru yang kreatif, sehingga dapat meringankan beban pemerintah dalam menyediakan lapangan pekerjaan. Pengusaha dapat berkreasi dengan lebih leluasa dalam mengembangkan bisnis perdagangannya tanpa terbatas wilayah negara. Pengusaha dapat lebih kreatif dalam mengembangkan produk barang/ jasa.

Perkembangan teknologi di bidang informasi ternyata tidak hanya membawa manfaat yang begitu besar. Kemudahan yang ditawarkan oleh fasilitas internet ini dapat digunakan oleh pihak-pihak tidak bertanggung jawab untuk melakukan kejahatan. Semakin maju dan modern kehidupan masyarakat, maka semakin maju dan modern pula jenis dan modus operandi kejahatan yang terjadi di tengah masyarakat. ${ }^{11}$ Kejahatan erat kaitannya dan bahkan menjadi bagian dari hasil budaya itu sendiri. Ini berarti semakin tinggi tingkat budaya dan semakin modern suatu bangsa, maka semakin modern pula kejahatan itu dalam bentuk, sifat, dan cara pelaksanaannya. ${ }^{12}$

Seiring dengan perkembangan teknologi di bidang informasi, maka jenis dan ragam kejahatan pun berkembang dengan memanfaatkan fasilitas yang telah disediakan oleh teknologi tersebut yang biasa disebut cybercrime. Dalam beberapa literatur, beberapa penulis menggunakan terminologi yang berbeda-beda untuk menyebut jenis tindak pidana ini. Barda Nawawi Arief ${ }^{13}$, Abdul Wahid dan Mohammad Labib ${ }^{14}$ menggunakan istilah tindak pidana mayantara. Berbeda dengan mereka, menurut Budi Suhariyanto penggunaan terminologi yang lebih tepat adalah tindak pidana atau kejahatan teknologi informasi ${ }^{15}$, sedangkan menurut Sigid Suseno, terminologi yang lebih tepat dalam bahasa Indonesia adalah tindak pidana siber. $^{16}$

10 Nur Farida Ahniar, 2011, “Berapa Pengguna Kartu Kredit di Indonesia?", < http://bisnis.news. viva.co.id/news/read/262391-berapa-pengguna-kartu-kredit-di-indonesia-> [24/09/2013]

11 Abdul Wahid dan Mohammad Labib, Kejahatan Mayantara (cyber crime), Rafika Aditama, Bandung, 2005, hlm.

12 J. E. Sahetapy dalam Abdul Wahid dan Mohammad Labib, ibid, hlm 36

13 Barda Nawawi Arief, Kapita Selekta Hukum Pidana, Citra Aditya Bakti, Bandung, 2003, hlm 255.

14 Abdul Wahid dan Mohammad Labib, Op Cit, hlm 39

15 Budi Suhariyanto, Tindak Pidana Teknologi Informasi (Cybercrime): Urgensi Pengaturan dan Celah Hukumnya, Rajawali Pers, Jakarta, 2013, hlm 11.

16 Sigid Suseno, Yurisdiksi Tindak Pidana Siber, Refika Aditama, Bandung, 2012, hlm 91 
Sebagaimana telah disampaikan di depan bahwa kejahatan selalu berkembang mengikuti perkembangan manusia. Begitu pula dengan jenis kejahatan siber (cybercrime) ini, selalu berkembang seiring dengan perkembangan teknologi dan juga perkembangan manusia dalam memanfaatkan teknologi tersebut. Tindak pidana siber pada awalnya hanya mencakup computer crime, yaitu kejahatan yang ditujukan pada komputer (mencuri atau merusak data atau program komputer) atau komputer sebagai alat untuk melakukan kejahatan. ${ }^{17}$ Saat ini terdapat berbagai macam jenis tindak pidana siber (cybercrime) diantaranya, phishing, spoofing, hacking, cracking, digital piracy, cyberstalking, cybersquatting, cyber terrorism, cyber pornography, identity theft, dan masih banyak lagi jenis-jenis tindak pidana siber lainnya. Diantara begitu banyak, salah satu tindak pidana yang timbul sebagai akibat buruk dari perkembangan teknologi informasi ini adalah credit card fraud.

Credit card fraud adalah penggunaan yang tidak sah dari kartu kredit dengan tujuan memperoleh sesuatu yang berharga dengan maksud untuk menipu. ${ }^{18}$ Lebih lengkap, Tej Paul Bhatla mendefinisikan bahwa terjadi credit card fraud ketika seseorang menggunakan kartu kredit orang lain untuk alasan (kepentingan) pribadi sedangkan pemilik kartu dan penerbit kartu tidak menyadari fakta bahwa kartu miliknya sedang digunakan. Selanjutnya, seseorang tersebut menggunakan kartu tanpa ada hubungannya dengan pemegang kartu atau penerbit, dan tidak memiliki niat baik untuk menghubungi pemilik kartu atau membuat pembayaran atas pembelian yang dilakukannya. ${ }^{19}$

Kejahatan ini merupakan salah satu jenis kejahatan di bidang teknologi informasi yang sangat meresahkan para pengguna kartu kredit di seluruh dunia termasuk di Indonesia. Di antara beberapa jenis tindak pidana siber, credit card fraud merupakan tindak pidana yang paling banyak terjadi di Indonesia. Pada bulan januari sampai september 2002, pihak Kepolisian Republik Indonesia telah mengungkap 109 kasus tindak pidana TI (Teknologi Informasi) dan $96 \%$ dari total 109 kasus tersebut adalah tindak pidana credit card fraud. ${ }^{20}$ Masalah yang ditimbulkan oleh jenis kejahatan ini memiliki skala yang sangat besar mengingat tingginya nilai transaksi dengan menggunakan kartu kredit di Indonesia. Korban tindak pidana siber yang dilakukan oleh pelaku dari Indonesia tersebar di berbagai benua mulai dari Asia, termasuk di Indonesia sendiri, Australia, Eropa Sampai Amerika dan mencapai kerugian - untuk carding atau credit card fraud saja - lebih dari Rp. 11,6 Milyar. ${ }^{21}$

Menurut Brigjen Anton Tabah, Staf Ahli Kapolri, jumlah cybercrime yang terjadi di Indonesia adalah yang tertinggi di dunia karena banyaknya aktivitas para hacker. Tingginya kasus cybercrime dapat dilihat dari banyaknya kasus pemalsuan kartu kredit dan pembobolan sejumlah bank. Tahun 2004 kejahatan carding mencapai 177 dari 192 kasus kejahatan

17 David Wall dalam Sigid Suseno, ibid, hlm 95

18 Wall, April D. (ed), Credit Card Fraud, Fairmont, National White Collar Crime Center, 2008, hlm 1 diunduh dari <http://www.nw3c.org/ docs/whitepapers/credit_card_fraud_(06-08) 86CD30ABEEBD3AAAB5DF904C.pdf?sfvrsn=3>[1/07/2013]

19 Bhatla, Tej Paul (eds), "Understanding Credit Card Frauds", Cards Business Review\#2003-01, 2003, hlm. 1 diunduh dari <http://www.pop center.org/problems/credit_card_fraud/PDFs/ Bhatla.pdf> [23/08/2013]

20 Abdul Wahid dan Mohammad Labib, Op Cit, hlm 26-27

21 Sigid Suseno, Op Cit, hlm2-3 
internet. Tahun sebelumnya, kejahatan carding menembus angka 145 dari 153 kasus kejahatan internet. ${ }^{22}$ Peringkat Indonesia dalam kejahatan di dunia maya (menggunakan internet) telah menggantikan posisi Ukraina yang sebelumnya menduduki peringkat pertama. $^{23}$

Wacana hukum tentang kejahatan credit card fraud di Indonesia masih tergolong baru padahal Indonesia merupakan negara dengan tingkat kejahatan credit card fraud tertinggi di dunia. Hal ini mengindikasikan adanya permasalahan terkait dengan credit card fraud dalam sistem hukum di Indonesia. Masalah yang dimaksud mungkin saja terjadi dalam salah satu sub sistem hukum baik substansi hukum, struktur hukum, maupun kultur hukum. Dalam substansi hukum, kemungkinan pengaturan hukum di Indonesia tidak dapat atau tidak cukup dapat menjangkau terhadap credit card fraud. Dalam struktur hukum, kemungkinan penegak hukum kurang memiliki pemahaman yang cukup atas hukum yang berlaku di Indonesia terkait dengan dengan credit card fraud, maupun pemahaman atas jenis tindak pidana credit card fraud itu sendiri. Dapat juga dalam hal kurang memadainya sarana dan prasarana penunjang yang dimiliki oleh penegak hukum. Dalam hal kultur hukum, indikasi masalah itu ada pada kurangnya kesadaran hukum dari masyarakat khususnya pengguna teknologi informasi terkait penggunaan kartu kredit.

Sebelum diberlakukannya Undang-Undang Nomor 11 Tahun 2008 Tentang Informasi dan Transaksi Elektronik (ITE), instrumen hukum yang digunakan oleh penegak hukum Indonesia adalah KUHP dengan pasal-pasal tentang penipuan dan pemalsuan. Tentunya penegak hukum harus bekerja keras dalam menafsirkan pasal-pasal tersebut supaya dapat digunakan untuk menjerat tindak pidana credit card fraud. Pada dasarnya memang tindak pidana credit card fraud merupakan penipuan. Akan tetapi, apabila dilihat dari pengertiannya, maka jelas credit card fraud berbeda dengan penipuan sebagaimana diatur dalam Pasal 378 KUHP.

Sejak tanggal 21 April 2008, ada beberapa perubahan dalam hukum pidana Indonesia dengan diberlakukannya UU Nomor 11 Tahun 2008 tentang ITE. Sejak diberlakukannya undang-undang ini Indonesia memiliki payung hukum baru khususnya berkenaan dengan Informasi dan Transaksi Elektronik. Banyak kalangan menyebut undang-undang ini sebagai hukum siber Indonesia. Undang-undang ini mengkriminalisasi beberapa perbuatan yang sebelumnya belum pernah diatur di dalam KUHP maupun undang-undang hukum pidana lainnya. Perbuatan-perbuatan yang dikriminalisasi tersebut diatur di dalam Pasal 27 sampai dengan Pasal 37. Pada intinya, perbuatan yang dikriminalisasi tersebut merupakan tindak pidana-tindak pidana yang menjadikan suatu sistem elektronik sebagai target, tindak pidana yang menggunakan suatu jaringan sistem elektronik sebagai sarana/ alat.

Berdasarkan pada hasil sebuah penelitian ditemukan beberapa kasus credit card fraud yang terjadi di beberapa daerah seperti Sumatera Utara, Jawa Barat dan Jawa Timur dalam

22 Dewi Bunga, Prostitusi Cyber: Diskursus Penegakan Hukum Dalam Anatomi Kejahatan Transnasional, Udayana University Press, Denpasar, 2012, hlm 4

23 Budi Suhariyanto, Op Cit, hlm 17 
selang waktu dari tahun 2004-2008. Jumlah kasus terbanyak terjadi di wilayah Kepolisian Daerah Jawa Barat. Setiap kasus credit card fraud yang ditemukan tersebut, dijerat dengan pasal-pasal penggelapan dan atau penipuan di dalam KUHP. Bahkan pada beberapa kasus yang terjadi pada tahun 2008 setelah berlakunya UU Nomor 11 tahun 2008 tentang Informasi dan Transaksi Elektronik, penyidik tetap menjerat mereka dengan menggunakan KUHP. ${ }^{24}$ Dalam penelitian tersebut tidak dijelaskan alasan penegak hukum memilih menerapkan KUHP dari pada UU Nomor 11 tahun 2008. Dimungkinkan penegak hukum belum mengetahui bahwa UU Nomor 11 tahun 2008 telah berlaku atau penegak hukum belum memahami setiap pasal yang diatur dalam undang-undang tersebut.

\section{B. Rumusan Permasalahan}

Berdasarkan pada latar belakang sebagaimana penulis uraikan di atas, maka penulis tertarik untuk mengkaji masalah-masalah sebagai berikut:

1. Bagaimana karakteristik tindak pidana credit card fraud?

2. Bagaimana Rumusan Pengaturan Credit Card Fraud dalam Hukum Pidana Indonesia jika ditinjau dari asas Legalitas?

\section{Metode Penelitian}

Jenis Penelitian yang peneliti gunakan dalam melakukan penelitian ini adalah penelitian Yuridis Normatif, yaitu suatu penelitian yang mengutamakan pengkajian terhadap ketentuanketentuan hukum positif mauun asas-asas hukum umum. Penelitian hukum normatif merupakan penelitian dengan mendasarkan pada bahan hukum baik primer maupun sekunder. $^{25}$

Kajian normatif melihat hukum dalam karakternya yang normatif berisi kaidah atau penormaan. Sebagai kaidah atau norma, hukum menentukan apa yang boleh dan apa yang tidak boleh dilakukan. Kajian ini bersifat perspektif, yaitu bersifat menentukan apa yang salah dan apa yang benar. Dengan kata lain kajian normatif berisi tentang apa yang seharusnya (das sollen). ${ }^{26}$ Kajian normatif juga memandang hukum sebagai sebuah sistem kaidah hukum yang tersusun secara hierarkis, dimana kaidah hukum yang lebih rendah diderivasi dari kaidahkaidah hukum yang lebih tinggi. ${ }^{27}$ Lebih lanjut dikemukakan oleh Harjono sebagaimana dikutip oleh johnny Ibrahim bahwa dalam kajian normatif seorang peneliti harus melihat hukum sebagai sebuah sistem tertutup yang mempunyai ciri-ciri sebagai berikut:

1. Comprehensive artinya norma-norma hukum yang ada di dalamnya terkait antara satu dengan lainnyasecara logis

${ }^{24}$ Sigid Suseno, Op Cit, hlm 140-144

25 Soerjono Soekanto dan Sri Pamudji, Pengantar Penelitian Normatif, Rajawali Pers, Jakarta, 1985, hlm. 15

26 Ahmad Ali, Menjelajah Kajian Empiris Terhadap Hukum, Yarsif Watampone, Jakarta, hlm.3

27 J.J.H. Bruggink, Refleksi Tentang Hukum, Alih Bahasa Bernard Arief Sidharta, Citra Aditya Bhakti, Bandung, 1999, hlm 15 
2. All-inclusive, bahwa kumpulan norma hukum tersebut cukup mampu menampung permasalahan hukum yang ada, sehingga tidak akan ada kekurangan hukum

3. Systematic, bahwa di samping bertautan satu sama lain, norma hukum juga tersusun secara hierarkis. ${ }^{28}$

Agar dapat memperoleh kebenaran ilmiah yang diharapkan, maka dalam penelitian ini dipergunakan beberapa pendekatan, yaitu conceptual approach (pendekatan konseptual) dan pendekatan undang-undang (statute approach). Sumber data digunakan adalah Data Sekunder yang terdiri dari berbagai jenis bahan hukum diantaranya bahan hukum primer, bahan hukum sekunder dan bahan hukum tersier. Bahan hukum primer meliputi Undang-Undang Dasar 1945, Undang-Undang dan peraturan pelaksanaan lainnya. Bahan hukum sekunder meliputi bahan-bahan yang mendukung bahan hukum primer seperti Buku-Buku Teks, Artikel, Hasil Penelitian, Makalah-Makalah, serta berita-berita hukum. Bahan hukum tersier meliputi Kamus Hukum, Kamus Umum dan Ensiklopedia.

Untuk memperoleh bahan hukum yang relevan guna menemukan jawaban ilmiah atas isu yang dirumuskan, maka teknik pengumpulan data yang peneliti gunakan adalah dengan studi kepustakaan dan dokumentasi. Dengan metode ini diharapkan akan diperoleh bahan hukum yang lengkap dan mendalam tentang topik dari penelitian. Teknik analisa data yang akan dilakukan oleh peneliti adalah dengan menggunakan metode deskriptif analitik yaitu dengan mengemukakan semua data yang diperoleh di lapangan kemudian diolah dan analisa berdasarkan teori dan ketentuan hukum yang selanjutnya dicari suatu kesimpulan atas permasalahan yang diteliti.

\section{Pembahasan}

\section{Karakteristik Tindak Pidana Credit Card Fraud}

Terdapat beberapa pengertian credit card fraud dari beberapa ahli dan organisasi terkait. National White Collar Crime Center dalam artikel yang berjudul Credit Card Fraud memberikan pengertian, bahwa:

"Credit card fraud is the unauthorized use of a credit card with the purpose of obtaining anything of value with the intent to defraud." 29

Pengertian tersebut dapat diterjemahkan bahwa Credit card fraud adalah penggunaan tidak sah sebuah kartu kredit dengan tujuan memperoleh sesuatu yang berharga dengan maksud untuk menipu. Lebih lengkap, Tej Paul Bhatla mendefinisikan bahwa terjadi credit card fraud dalam hal:

"When an individual uses another individuals' credit card for personal reasons while the owner of the card and the card issuer are not aware of the fact that the card is being used. Further, the individual using the card has no connection with the cardholder or

28 Johnny Ibrahim, Teori dan Metode Hukum Normatif, Bayumedia, Malang, 1995, hlm 249.

29 Wall, April D. Wall, op cit. 
issuer, and has no intention of either contacting the owner of the card or making repayments for the purchases made." 30

Definisi tersebut dapat diterjemahkan bahwa terjadi credit card fraud ketika seseorang menggunakan kartu kredit orang lain untuk alasan (kepentingan, pen) pribadi sedangkan pemilik kartu dan penerbit kartu tidak menyadari bahwa kartu miliknya sedang digunakan. Selanjutnya, seseorang tersebut menggunakan kartu tanpa ada hubungannya dengan pemegang kartu atau penerbit, dan tidak memiliki niat baik untuk menghubungi pemilik kartu atau membuat pembayaran atas pembelian yang dilakukannya. Berdasarkan pada dua pengertian tersebut dapat penulis ambil pengertian bahwa credit card fraud adalah tindakan seseorang menggunakan kartu kredit milik orang lain secara melawan hak dengan tujuan untuk mendapatkan sesuatu yang berharga baik untuk menguntungkan dirinya sendiri maupun orang lain dengan maksud untuk menipu.

Merujuk kepada pengertian tersebut, untuk dapat melakukan tindak pidana credit card fraud, pelaku harus mendapatkan (secara melawan hukum) kartu kredit milik orang lain terlebih dahulu. Kartu kredit yang dimaksud baik kartu kredit dalam bentuk fisik, maupun data elektronik yang berisi informasi identitas pribadi tentang kepemilikan kartu kredit yang terekam di dalam kartu seperti nama penerbit kartu, nama pemegang kartu, nomer kartu, masa berlaku kartu, maupun nomor verifikasi kartu atau CVV (Card Verification Value). Perbuatan penguasaan data identitas pribadi seseorang secara melawan hukum tersebut disebut identity theft.

Identity Theft terjadi ketika seseorang memperoleh/ mendapatkan, mengirim, memiliki, atau menggunakan informasi pribadi dari seseorang atau suatu badang hukum dengan cara yang tidak sah, dengan maksud untuk melakukan, atau sehubungan dengan, penipuan atau kejahatan lainnya. ${ }^{31}$ kejahatan ini jarang dilakukan dengan menjadikan informasi identitas pribadi sebagai target tujuannya. Sebaliknya, kejahatan ini hampir selalu dijadikan sebagai sarana untuk memudahkan kejahatan lain, biasanya kejahatan dalam bidang keuangan dengan memperkaya diri pelaku dengan mengorbankan individu, bisnis, lembaga keuangan, maupun lembaga pemerintah. ${ }^{32}$ Identity theft ini merupakan perbuatan pendahuluan sebagai sarana untuk melakukan suatu tindak pidana.

Tindak pidana credit card fraud ini, terdapat dua tahap besar. Tahap pertama, sebelum dapat melakukan tindak pidana credit card fraud, pelaku harus mendapatkan kartu kredit (milik orang lain) atau informasi elektronik berkenaan dengan kartu kredit tersebut terlebih dahulu, seperti ID Number, expiry date, CVV Number, dsb. Terdapat beberapa teknik/ cara untuk mendapatkan kartu kredit ataupun informasi di dalamnya tersebut misalnya skimming, phishing, hacking, social engeenering, dll. Teknik atau metode-metode dalam tahap ini

30 Bhatla, Tej Paul, op cit

31 OECD, Scoping Paper on Online Identity Theft, Ministerial Backgroud Report: DSTI/CP (2007)/FINAL, hlm 12, 2008, diunduh dari <http://www.oecd.org/sti/40644196.pdf> [10/7/2013]

32 Depository Institutions of Financial Crimes Enforcement Network, Identity Theft: Trends, Patterns, and typologies Reported in suspicious Activity Reports, 2010, hlm 1, diunduh dari < http://www.fincen.gov/news_room/rp/reports/pdf/ID\%20Theft.pdf>[15/05/2013] 
disebut sebagai identity theft. Tahap kedua adalah penggunaan data informasi pribadi dari kartu kredit untuk melakukan transaksi tanpa ijin dari pemegang sah kartu kredit.

Berdasarkan pada penjabaran di atas, dapat dipahami karakter tindak pidana credit card fraud bahwa tindak pidana credit card fraud, selalu terdiri dari, minimal, dua tindak pidana, yaitu pertama adalah identity theft, dan kedua adalah tindak pidana credit card fraud itu sendiri. Pelaku menggunakan kartu kredit milik orang lain yang dikuasainya untuk mendapatkan keuntungan secara finansial baik untuk dirinya sendiri maupun orang lain secara melawan hukum. Karakteristik yang dimiliki oleh credit card fraud tersebut, dalam ajaran hukum pidana, dikualifikasikan sebagai concursus.

Menurut Khyati Chaundhary dan Bhawna Mallick ${ }^{33}$, Transaksi berbasis kartu kredit dapat diklasifikasikan menjadi dua jenis. Pertama, transaksi menggunakan kartu kredit dalam bentuk fisik, dan kedua transaksi kartu jarak Jauh. Pada transaksi menggunakan kartu kredit dalam bentuk fisik, pemegang kartu memberikan kartunya secara fisik ke pedagang (merchant) untuk melakukan pembayaran. Credit card fraud dengan menggunakan metode ini, pelaku harus memiliki kartu kredit dalam bentuk fisik.

Kedua, transaksi kartu jarak Jauh (biasa disebut transaksi on-line), pada transaksi jenis ini, hanya membutuhkan beberapa informasi penting tentang kartu, seperti nama pemegang kartu kredit, nomer kartu kredit, Tanggal Kadaluarsa, kode pengaman, nomer verifikasi kartu kredit (CVV) untuk melakukan pembayaran. Untuk melakukan penipuan dalam jenis transaksi ini, pelaku perlu mengetahui rincian informasi penting tentang kartu. Rincian data itulah yang diberikan kepada pedagang (merchant) sebagai alat pembayaran. Dengan informasi itulah pedagang akan membebankan beban pembayaran kepada account (rekening) kartu kredit milik pemegang yang sah.

Berdasarkan pada penjabaran di atas, penulis dapat menyimpulkan bahwa terdapat beberapa skema credit card fraud diantaranya:

a. Pelaku menggunakan kartu kredit (dalam bentuk fisik) asli yang didapatkannya secara melawan hukum untuk berbelanja barang dan/ atau jasa di toko-toko yang menerima pembayaran dengan kartu kredit, atau menarik uang tunai di mesin ATM yang tentu saja tanpa seijin atau sepengetahuan pemegang sah dari kartu kredit.

b. Pelaku menggunakan kartu kredit (dalam bentuk fisik) palsu yang telah dibuatnya untuk berbelanja barang dan/ atau jasa di toko-toko yang menerima pembayaran dengan kartu kredit tanpa seijin atau sepengetahuan pemegang sah dari kartu kredit.

c. Palaku menggunakan data elektronik terkait kartu kredit seperti nomer kartu kredit, nama pemegang, nama penerbit, tanggal kadaluarsa, kode pengaman, dan nomer varifikasi kartu kredit (CVV: Card Verification Value) untuk berbelanja barang dan/ atau jasa secara on-line dengan menyebutkan/ memberikan data kartu kredit tersebut kepada pedagang.

33 Chaudhary, Khyati dan Mallick, Bhawna, Credit Card Fraud: The study of its impact and detection, International Journal of Computer Science and Network (IJCSN) Volume 1, Issue 4, August 2012, ISSN 2277-5420, hlm 31-32. diunduh dari < www.ijcsn.org >[22/09/2013] 


\section{Rumusan Pengaturan Credit Card Fraud dalam Hukum Pidana Indonesia Ditinjau dari Asas Legalitas.}

Hukum pidana Indonesia memiliki asas pokok yang dijadikan dasar utama. Asas pokok tersebut adalah asas legalitas. Sebagaimana telah penulis jabarkan di dalam bab sebelumnya bahwa asas ini mengandung pengertian bahwa tidak ada delik, tidak ada pidana tanpa peraturan yang mengaturnya lebih dahulu. Artinya, suatu perbuatan tidak dapat dipidana kecuali berdasarkan peraturan perundang-undangan pidana yang telah ada dan berlaku. Penegakan hukum terhadap suatu tindak pidana hanya dapat dilakukan berdasarkan atas peraturan perundang-undangan pidana yang telah berlaku. Hal ini menunjukkan bahwa komponen subtansi hukum pidana memiliki pengaruh yang besar terhadap kualitas penegakan hukum pidana, termasuk penegakan hukum pidana credit card fraud.

Dalam bagian sebelumnya telah penulis jabarkan bahwa di dalam asas legalitas terkandung tiga makna atau syarat. Pertama, peraturan hukum pidana harus tertulis (lex scipta). Kedua, peraturan hukum pidana harus jelas dan tegas sehingga tidak menyebabkan multi tafsir (lex certa). Dan ketiga, peraturan hukum pidana harus diterapkan dengan ketat tanpa adanya analogi (lex stricta). Ketiga makna ini menjadi syarat yang harus dipenuhi di dalam penegakan hukum pidana di Indonesia. Berdasarkan hal tersebut dapat dipahami bahwa asas legalitas tidak hanya berada pada dimensi penegakan hukum, melainkan juga pada dimensi pembentukan hukum. Hal tersebut dapat dilihat dari syarat kedua dimana peraturan hukum pidana harus jelas dan tidak multi tafsir. Dalam proses pembentukan hukum pidana, pengaturan hukum pidana harus disusun dengan bahasa yang jelas dan tegas.

Pada dasarnya, kualitas suatu peraturan hukum pidana dapat diukur dengan menggunakan syarat tersebut. Suatu peraturan hukum pidana dapat dikatakan baik apabila peraturan tersebut disusun dengan bahasa yang jelas dan tegas. Artinya, rumusan unsur tindak pidana yang termuat di dalam peraturan pidana harus spesifik dan tidak menggunakan bahasa yang ambigu. Hal ini untuk meminimalisir adanya multi tafsir dalam penerapannya. Perumusan unsur tindak pidana yang spesifik akan menutup kemungkinan penggunaan penafsiran analogi yang dilarang dalam hukum pidana. Untuk itu, dalam penyusunan peraturan hukum pidana dibutuhkan peraturan lengkap mengatur setiap jenis tindak pidana yang diancam dengan sanksi pidana.

Begitu pula dalam penyusunan peraturan hukum pidana tentang credit card fraud, sebaiknya menggunakan perumusan dengan bahasa yang spesifik terkait dengan credit card fraud dan tidak menggunakan bahasa yang bersifat umum. Hal ini akan meringankan kerja hakim untuk menafsirkannya sehingga kepastian hukum dapat tercapai. Penggunaan bahasa yang bersifat spesifik akan membawa dampak sempitnya lingkup perbuatan yang dilarang. Untuk itu, dibutuhkan perumusan tindak pidana yang lebih lengkap terkait setiap jenis tindak pidana yang termasuk dalam jenis tindak pidana credit card fraud.

Sebagaimana telah penulis jabarkan di dalam bab 3, tindak pidana credit card fraud memiliki karakteristik yang berbeda dengan tindak pidana pada umumnya. Untuk dapat menyelesaikan tindak pidana ini dibutuhkan beberapa tahapan. Tahap pertama, tahapan untuk 
mendapatkan kartu kredit milik orang lain (korban) secara melawan hukum. Kartu kredit yang dimaksud dapat berupa kartu kredit dalam bentuk fisik kartu maupun data elektronik terkait identitas kartu kredit yang tersimpan di dalam pita magnetik di bagian belakang kartu. Tahap kedua adalah tahap penggunaan kartu kredit milik orang lain untuk bertransaksi untuk mendapatkan keuntungan tanpa sepengetahuan dan seijin dari pemegang kartu kredit yang sah.

Pada tahap yang kedua tersebut juga dapat dilakukan dengan beberapa cara. Pertama, pelaku menggunakan kartu kredit (dalam bentuk fisik kartu) milik orang lain secara melawan hukum untuk bertransaksi dengan tujuan untuk mendapatkan keuntungan. Kedua, pelaku menggunakan kartu kredit (dalam bentuk fisik kartu) milik orang lain yang telah dipalsukan untuk bertransaksi dengan tujuan untuk mendapatkan keuntungan. Dan ketiga, menggunakan data elektronik identitas kartu kredit milik orang lain untuk bertransaksi melalui perdagangan elektronik dengan tujuan untuk mendapatkan keuntungan. Pada dasarnya ketiga cara itu memang memiliki kesamaan yaitu menggunakan kartu kredit orang lain untuk bertransaksi, akan tetapi ketiga cara tersebut memiliki unsur perbuatan yang jelas berbeda satu sama lain dan menggunakan media yang juga berbeda.

Kedua tahapan tersebut masing-masing merupakan tindak pidana yang berdiri sendiri. Dua tahapan yang diperlukan dalam melakukan tindak pidana tersebut merupakan tahapan minimal yang harus dilakukan oleh pelaku tindak pidana credit card fraud. Tidak menutup kemungkinan pelaku juga akan menggunakan cara-cara lain dalam melancarkan aksinya untuk mendapatkan keuntungan yang diinginkan.

Berdasarkan hasil studi kepustakaan, peneliti menemukan beberapa skema digunakan oleh pelaku tindak pidana credit card fraud. peneliti juga telah melakukan studi terhadap peraturan perundang-undangan pidana dalam sistem hukum pidana Indonesia. Peneliti tidak menemukan peraturan khusus yang mengatur tentang pemberantasan tindak pidana credit card fraud. Penulis hanya menemukan beberapa pasal dalam beberapa peraturan perundangundangan yang dapat diterapkan dalam penegakan hukum credit card fraud.

Dalam bab sebelumnya telah dijabarkan mengenai beberapa cara yang dapat dipakai atau dilakukan oleh pelaku sekaligus sebagai bentuk credit card fraud dalam mengambil keuntungan dari kartu kredit milik orang lain. Beberapa bentuk credit card fraud tersebut adalah sebagai berikut:

a. Menggunakan kartu kredit asli yang telah didapatkannya untuk mendapatkan keuntungan.

Bentuk pertama ini pelaku menggunakan kartu kredit asli milik orang lain yang telah pelaku dapatkan. Bentuk ini sangat jarang digunakan oleh pelaku credit card fraud. Ketika kartu kreditnya hilang, maka pemilik akan segera menyadari dan segera mengajukan pemblokiran kepada penerbit kartu kredit. Pasca kartu kredit diblokir, maka tentunya kartu beserta data/ elektronik yang berada di dalamnya sudah tidak dapat dipakai. 
Meskipun bentuk ini sangat jarang digunakan, tidak menutup kemungkinan bentuk ini tetap digunakan. Tidak semua pelaku tindak pidana ini berpengalaman, bahkan banyak yang masih dalam taraf mencoba. Tidak semua pemegang atau pengguna kartu kredit yang menyadari betapa besar ancaman tindak pidana credit card fraud sehingga kurang berhati-hati dalam menjaganya. Oleh karena itulah bentuk ini masih mungkin terjadi meskipun kecil.

Jika dipahami, rumusan perbuatannya maka credit card fraud dengan menggunakan bentuk ini adalah dengan sengaja dan tanpa hak mengambil keuntungan dari kartu kredit milik orang lain. Setelah penulis pelajari, penulis tidak menemukan adanya pengaturan dalam sistem hukum pidana Indonesia yang sesuai dengan rumusan perbuatan tersebut. Di dalam peraturan perundang-undangan tentang perbankan, dimana seharunya nasabah kartu kredit mendapatkan perlindungan hukum, juga tidak memberikan pengaturan tentang tindak pidana ini.

b. Menggunakan kartu kredit yang telah dipalsukan untuk mendapatkan keuntungan

Kartu kredit yang digunakan dalam bentuk ini adalah kartu kredit palsu. Meskipun kartu kredit ini palsu, akan tetapi tetap dapat digunakan sebagai alat pembayaran. Sebagaimana telah penulis sampaikan, bahwa yang dipalsukan hanyalah fisik kartu, sedangkan data/ informasi kartu kredit yang terekam di dalam kartu kredit tersebut sepenuhnya valid milik orang lain yang terdaftar pada penerbit kartu kredit. Pelaku menginput atau memasukkan data/ informasi kartu kredit yang valid milik orang lain yang telah diperolehnya ke dalam pita magnetik kartu kredit palsu. Pada proses pembayaran, mesin EDC membaca data/ informasi elektronik yang terekam dalam kartu kredit untuk melakukan verifikasi. Dengan validnya data tersebut, maka mesin EDC dapat mengenali data/ informasi tersebut, sehingga menerima transaksi pembayaran yang dilakukan.

Dalam melakukan perbuatannya, pelaku menggunakan kartu kredit yang telah dipalsukannya untuk bertransaksi dengan tujuan mendapatkan keuntungan tanpa menanggung beban pembayaran. Beban pembayaran akan ditagihkan kepada pemegang kartu kredit yang sah. Melihat bentuk perbuatannya, maka dapat diketahui bahwa rumusan perbuatannya adalah menggunakan kartu kredit palsu milik orang lain yang seolah-olah kartu kredit tersebut asli untuk mendapatkan keuntungan yang menimbulkan kerugian bagi orang lain.

c. Menggunakan data/ informasi elektronik kartu kredit sebagai alat pembayaran dalam transaksi perdagangan elektronik (e-commerce)

Dalam transaksi perdagangan elektronik (e-commerce), tidak terjadi pertemuan tatap muka secara langsung. Transaksi perdagangan, baik pemilihan barang atau jasa, maupun proses pembayaran hanya dilakukan melalui situs yang telah disediakan oleh pedagang. Begitu pula pada tahap pembayaran, transaksi dilakukan secara online. Pada tahap proses pembayaran, pedagang hanya meminta pembeli untuk memasukkan data/ informasi kartu kredit yang akan digunakannya sebagai alat pembayaran serta alamat pengiriman barang. Setelah pedagang berhasil melakukan otentifikasi terhadap kartu kredit, pedagang 
bersedia melakukan transaksi dengan pembeli. Dalam anggapan pedagang, pembeli adalah pemegang kredit yang sah, karena pembeli mengetahui data/ informasi elektronik kartu bersifat pribadi yang harus dirahasikan.

Dalam proses transaksi on-line tersebut pelaku tindak pidana credit card fraud membuat pedagang percaya bahwa dirinya adalah pemegang sah dari kartu kredit. Pelaku memberikan data sesuai dengan data/ informasi elektronik kartu kredit. Pelaku juga mengaku sebagai pemegang kartu kredit yang sah dengan menyebutkan identitas sesuai dengan data elektronik kartu kredit. dengan cara itu, pedagang percaya bahwa pelaku adalah pemegang kartu kredit yang sah, sehingga pedagang bersedia melakukan transaksi perdagangan dengan pelaku.

Di dalam sistem hukum pidana Indonesia, tidak terdapat peraturan perundang-undangan yang spesifik mengatur tentang credit card fraud. Pada tahun 2008, Indonesia telah melahirkan sebuah reim hukum pidana baru dengan diberlakukannya UU Nomor 11 Tahun 2008 Tentang Informasi dan Transaksi Elektronik. Banyak kalangan ahli hukum pidana menyebutnya sebagai hukum siber Indonesia. Setelah penulis perhatikan setiap isi pasal di dalamnya tidak ada satupun pasal yang mengatur tindak pidana credit card fraud.

Meskipun begitu, bukan berarti perbuatan tersebut dibiarkan bebas begitu saja. Perbuatan tersebut telah dikriminalisasi sebagai tindak pidana mengingat tingginya angka kejadian dan juga besarnya kerugian yang ditimbulkan. Banyak kasus tindak pidana credit card fraud yang telah ditangani oleh penegak hukum di berbagai daerah yang tentunya menggunakan hukum pidana yang telah berlaku seperti Kitab Undang-Undang Hukum Pidana (KUHP).

Untuk menentukan kualifikasi tindak pidana sekaligus hukum pidana yang mengaturnya, maka harus melihat berdasarkan bentuk perbuatan yang digunakan pelaku. Sebagaimana telah penulis jelaskan di atas, terdapat tiga bentuk perbuatan yang biasa dilakukan oleh pelaku dalam melakukan tindak pidana credit card fraud. Oleh karena itu, untuk menentukan kualifikasi tindak pidana sekaligus hukum pidana yang mengaturnya, maka perlu dilihat berdasarkan ketiga bentuk perbuatan yang digunakan pelaku tersebut.

Bentuk pertama, pelaku menggunakan kartu kredit asli milik orang lain untuk bertransaksi dengan tujuan mendapatkan keuntungan. Bentuk ini memiliki rumusan perbuatan bahwa pelaku dengan sengaja dan tanpa hak menggunakan kartu kredit milik orang lain untuk bertransaksi dengan tujuan untuk mendapatkan keuntungan yang pemakaiannya dapat menimbulkan kerugian. Penulis tidak menemukan satupun pengaturan dalam sistem hukum pidana Indonesia yang memenuhi unsur atau rumusan perbuatan pelaku tersebut.

Hal ini berarti bahwa perbuatan ini belum dikriminalisasi dalam hukum pidana Indonesia. Sedangkan perbuatan tersebut dapat membawa kerugian yang besar bagi pemegang kartu kredit yang sah, juga pihak bank atau penerbit kartu yang dapat mengganggu stabilitas keuangan bank. Dampak belum dikriminalisasikannya perbuatan tersebut adalah bahwa terhadap perbuatan tersebut, pelaku tidak dapat dibebani pertanggung jawaban pidana. Dengan kata lain, pelaku tidak dapat dipidana. 
Bentuk kedua, pelaku menggunakan kartu kredit yang telah dipalsukannya untuk bertransaksi dengan tujuan untuk mendapatkan keuntungan. Rumusan perbuatan dari credit card fraud bentuk kedua ini adalah dengan sengaja dan tanpa hak menggunakan kartu kredit yang dipalsukan untuk bertransaksi dengan tujuan mendapatkan keuntungan yang penggunaannya akan menimbulkan kerugian. Berdasarkan rumusan perbuatan tersebut dapat dipahami dengan mudah bahwa perbuatan tersebut terkualifikasi sebagai tindak pidana mempergunakan surat palsu sebagaimana diatur dalam Pasal 263 ayat (2) KUHP.

Rumusan Pasal 263 ayat (2) KUHP tersebut adalah Barang siapa dengan sengaja menggunakan surat palsu atau yang dipalsukan itu seolah-olah surat itu asli dan tidak dipalsukan, kalau hal mempergunakan dapat mendatangkan suatu kerugian. Memperhatikan rumusan pasal tersebut dengan rumusan perbuatan, dapat diketahui bahwa rumusan perbuatan yang dilakukan pelaku memenuhi setiap rumusan pasal. Kartu kredit palsu yang digunakan oleh pelaku adalah kartu kredit yang dipalsukan. Hal ini dapat diketahui bahwa data/ informasi elektronik yang terekam di dalam pita magnetik pada kartu adalah otentik sehingga diterima sebagai alat pembayaran. Dapat atau tidaknya kartu kredit sebagai alat pembayaran, bukan tergantung pada fisik kartu, melainkan tergantung pada data/ informasi elektronik yang terekam di dalam pita magnetik kartu kredit yang dapat dibaca oleh mesin EDC. Oleh karena itu, khusus terhadap perbuatan pada bentuk kedua ini, Pasal 263 ayat (2) KUHP dapat diterapkan dalam proses penegakan hukum credit card fraud.

Bentuk ketiga, menggunakan data/ informasi elektronik kartu kredit untuk bertransaksi dalam perdagangan elektronik dengan tujuan mendapatkan keuntungan. Pada perbuatan bentuk ketiga ini, pelaku mengelabuhi pedagang dengan berpura-pura sebagai pemegang kartu kredit yang sah dengan menyebutkan atau memberikan data/ informasi elektronik kartu kredit yang valid juga menyebutkan atau memberikan data identitas sesuai dengan data akun kartu kredit yang terdaftar di penerbit kartu. Jika proses verifikasi data/ informasi elektronik kartu kredit yang dilakukan oleh pedagang berhasil, maka pedagang bersedia melakukan transaksi perdagangan elektronik dengan pelaku. Setelah proses transaksi selesai, pedaganga membuat tagihan kepada akun kartu kredit yang tentunya akan dibebankan kepada pemegang kartu kredit yang sah.

Bentuk ketiga ini memiliki rumusan dengan sengaja dan tanpa hak menggunakan data/ informasi kartu kredit milik orang lain untuk bertransaksi dalam perdagangan elektronik dengan mengaku sebagai pemegang kartu kredit yang sah, membujuk pedagang untuk bersedia melakukan transaksi perdagangan dengan tujuan untuk mendapatkan keuntungan yang menimbulkan kerugian bagi orang lain. Merujuk kepada rumusan perbuatan tersebut, pada dasarnya perbuatan tersebut dapat dikualifikasi sebagai tindak pidana penipuan sebagaimana diatur dalam Pasal 378 KUHP. Rumusan pasal tersebut adalah sebagai berikut:

barang siapa dengan maksud hendak menguntungkan diri sendiri atau orang lain dengan melawan hak, baik dengan memakai nama palsu atau keadaan palsu, baik dengan akal dan tipu muslihat, maupun dengan keterangan perkataan-perkataan bohong, membujuk orang supaya memberikan sesuatu barang, membuat utang atau menghapuskan piutang, dihukum karena penipuan. 
Melihat rumusan pasal tersebut, maka dapat diketahui bahwa Pasal 378 KUHP memiliki unsur-unsur sebagai berikut:

a. Barang siapa

b. Dengan maksud

c. Hendak menguntungkan diri sendiri atau orang lain dengan melawan hak

d. Memakai nama palsu atau keadaan palsu

e. Dengan akal dan tipu muslihat atau dengan keterangan perkataan bohong

f. Membujuk orang supaya memberikan sesuatu barang, atau

g. Membuat utang, atau

h. Menghapuskan piutang

Untuk melihat dapat atau tidaknya Pasal 378 tersebut untuk menjerat perbuatan tersebut, maka harus diperhatikan kecocokan setiap unsur pasal dengan unsur perbuatannya. Dalam melakukan perbuatannya, pelaku pasti memakai nama dan juga keadaan palsu. Dalam transaksi perdagangan elektronik, pelaku selalu mengaku seolah-olah pemegang kartu yang sah dengan memakai nama pemegang kartu tersebut. Hal ini dapat dilakukan dengan begitu mudah, mengingat transaksi e-commerce dilakukan jarak jauh tanpa bertemu secara langsung.

Pada saat proses pembayaran menggunakan kartu kredit, pelaku selaku pembeli hanya perlu memberikan data/ informasi elektronik kartu kredit beserta identitas diri. Pada saat itulah pelaku memasukkan data/ informasi elektronik kartu kredit beserta data diri pemegang kartu yang sah. Pelaku berpura sebagai pemegang kartu kredit yang sah. Setelah pedagang berhasil melakukan verifikasi dan validasi data/ informasi kartu kredit yang diberikan pelaku, barulah pedagang bersedia melakukan transaksi. Pedagang membuat tagihan pembayaran dan melakukan pengiriman barang yang telah dipesan oleh pelaku.

Berdasarkan pada penjabaran tersebut, dapat dipahami bahwa terdapat perbedaan antara rumusan perbuatan dalam bentuk ketiga dengan rumusan pasal 378 KUHP tersebut. perbedaan tersebut pada tujuan pelaku dimana pada tindak pidana penipuan, tujuan pelaku adalah supaya korbannya menyerahkan barang, membuat utang, atau menghapuskan piutang. Tujuan pelaku dari credit card fraud bentuk ketiga ini adalah supaya pedagang bersedia melakukan transaksi perdagangan dengan pelaku menggunakan kartu kredit. Oleh karena itu dapat dipahami bahwa perbuatan pelaku tidak memenuhi rumusan pasal 378 KUHP

Tujuan di dalam tindak pidana penipuan adalah supaya korban menyerahkan suatu barang secara sukarela, membuat utang atau menghapuskan piutang atas pelaku. Sedangkan tujuan pelaku melakukan credit card fraud adalah supaya pedagang bersedia melakukan transaksi perdagangan dengan pembayaran menggunakan kartu kredit dengan pelaku. Pada dasarnya, transaksi menggunakan kartu kredit merupakan suatu bentuk hutang piutang. Akan tetapi, dalam kejahatan credit card fraud, beban pembayaran hutang tersebut dibebankan kepada pemegang kartu kredit yang sah bukan ditanggung oleh pelaku sendiri. Hal ini jelas berbeda dengan tujuan yang dimaksud di dalam pasal 378 KUHP. membuat hutang yang dimaksud di dalam Pasal 378 KUHP tersebut adalah hutang yang ditanggung pelaku sendiri. Dapat disimpulkan bahwa rumusan pasal 378 KUHP tidak memenuhi rumusan perbuatan credit card 
fraud dalam bentuk ketiga ini. oleh karena itu maka Pasal 378 KUHP ini tidak dapat diterapkan dalam menjerat pelaku credit card fraud.

Berdasarkan pada penjabaran di atas, dapat diketahui bahwa tidak semua perbuatan yang dilakukan dalam rangka melakukan kejahatan credit card fraud dapat dijangkau oleh hukum pidana Indonesia. Terdapat beberapa perbuatan yang tidak diatur atau dikriminalisasikan di dalam hukum pidana Indonesia. Terdapat pula beberapa pengaturan hukum pidana yang membutuhkan penafsiran analogi untuk dapat menjangkau perbuatan-perbuatan di dalam credit card fraud. Padahal asas legalitas melarang penggunaan penafsiran analogi di dalam hukum pidana.

\section{E. Penutup}

Berdasarkan hasil analisa terhadap data hasil penelitian sebagaimana tersebut di atas, maka penulis mendapatkan suatu kesimpulan sebagaimana tersebut di bawah ini:

1. Bahwa credit card fraud memiliki karakteristik yang berbeda dengan jenis tindak pidana lain. Credit card fraud merupakan gabungan dari beberapa jenis cybercrime. Terdapat dua tahapan dalam melakukan tindak pidana ini. pertama, pelaku harus mendapatkan kartu kredit (baik dalam bentuk fisik maupun informasi penting dari kartu kredit) dari calon korban. Kedua, pelaku dapat menggunakan kartu kredit tersebut untuk bertransaksi untuk mendapatkan keuntungan tanpa sepengetahuan dan seijin dari pemegang kartu yang sah. Masing-masing tahap tersebut merupakan tindak pidana.

2. Terdapat tiga modus yang biasa dilakukan pelaku dalam melakukan credit card fraud. Pertama, pelaku menggunakan kartu kredit kredit asli milik orang lain untuk bertransaksi. Kedua, pelaku mengunakan kartu kredit palsu yang di dalam pita manetnya telah diinputkan data identitas kartu kredit yang valid milik orang lain. Dan ketiga, pelaku menggunakan data identitas kartu kredit valid milik orang lain untuk melakukan transaksi perdagangan. Dari ketiga modus yang biasa dilakukan pelaku dalam melakukan credit card fraud tersebut, modus pertama tidak diatur di dalam hukum pidana Indonesia. Untuk modus kedua, diatur di dalam Pasal 263 KUHP ayat (2). Sedangkan untuk modus ketiga, tidak ditemukan pengaturan yang spesifik mengatur bentuk perbuatan tersebut. Masih dimungkinkan untuk menggunakan Pasal 378 KUHP tentang penipuan.

\section{Daftar Pustaka}

\section{Buku}

Abdul Wahid dan Mohammad Labib, Kejahatan Mayantara (cyber crime), Rafika Aditama, Bandung, 2005

Adi Nugroho, e-commerce: Memahami Perdagangan Modern di Dunia Maya, Informatika, Bandung, 2006 
Agus Raharjo, Cybercrime: Pemahaman dan Upaya Pencegahan Kejahatan Berteknologi, Citra Aditya Bakti, Bandung, 2002, hlm 2-3; Sutan Remy Syahdeini, Kejahatan dan Tindak Pidana Komputer, Grafiti, Jakarta, 2009

Ahmad Ali, Menjelajah Kajian Empiris Terhadap Hukum, Yarsif Watampone, Jakarta,

Barda Nawawi Arief, Kapita Selekta Hukum Pidana, Citra Aditya Bakti, Bandung, 2003

Bruggink, J.J.H., Refleksi Tentang Hukum, Alih Bahasa Bernard Arief Sidharta, Citra Aditya Bhakti, Bandung, 1999

Budi Suhariyanto, Tindak Pidana Teknologi Informasi (Cybercrime): Urgensi Pengaturan dan Celah Hukumnya, Rajawali Pers, Jakarta, 2013

Dewi Bunga, Prostitusi Cyber: Diskursus Penegakan Hukum Dalam Anatomi Kejahatan Transnasional, Udayana University Press, Denpasar, 2012

Dikdik M. Arief Mansur dan Elisatris Gultom, Cyber Law: Aspek Hukum Teknologi Informasi, Refika Aditama, Bandung, 2005

Johnny Ibrahim, Teori dan Metode Hukum Normatif, Bayumedia, Malang, 1995

McQuade, Samuel C., Encyclopedia of Cybercrime, London, Greenwood Press, 2009

Sigid Suseno, Yurisdiksi Tindak Pidana Siber, Refika Aditama, Bandung, 2012

Soerjono Soekanto dan Sri Pamudji, Pengantar Penelitian Normatif, Rajawali Pers, Jakarta, 1985

\section{Jurnal}

Bhatla, Tej Paul (eds), "Understanding Credit Card Frauds", Cards Business Review\#200301, 2003, diunduh dari <http://www.popcenter.org/problems/credit_card_fraud/ PDFs/Bhatla.pdf> [23/08/2013]

Chaudhary, Khyati dan Mallick, Bhawna, Credit Card Fraud: The study of its impact and detection, International Journal of Computer Science and Network (IJCSN) Volume 1, Issue 4, August 2012, ISSN 2277-5420, diunduh dari < www.ijcsn.org>[22/09/2013]

Wall, April D. (ed), Credit Card Fraud, Fairmont, National White Collar Crime Center, 2008, diunduh dari <http://www.nw3c.org/docs/whitepapers/credit_card_fraud_(0608)86CD30ABEEBD3AAAB5DF904C.pdf?sfvrsn=3>[1/07/2013]

\section{Internet}

Bank Indonesia, (tanpa Tahun) "Alat Pembayaran: Kartu ATM/Debet”, <http://www.bi.go.id/ web/id/Info+dan+Edukasi+Konsumen/Alat+Pembayaran/> [21/09/2013] 
Depository Institutions of Financial Crimes Enforcement Network, Identity Theft: Trends, Patterns, and typologies Reported in suspicious Activity Reports, 2010, diunduh dari < http://www.fincen.gov/news_room/rp/reports/pdf/ID\%20Theft.pdf>[15/05/2013]

Herdaru Purnomo, 2013, “Jumlah Pemegang Kartu Kredit Tembus 14 Juta, Satu Orang Punya 3 Kartu”, <http://finance.detik.com/read/2013/03/04/133250/2184937/5/jumlahpemegang-kartu-kredit-tembus-14-juta-satu-orang-punya-3-kartu> [24/09/2013]

Nur Farida Ahniar, 2011, “Berapa Pengguna Kartu Kredit di Indonesia?”, $<$ http://bisnis.news.viva.co.id/news/read/262391-berapa-pengguna-kartu-kredit-diindonesia-> [24/09/2013]

OECD, Scoping Paper on Online Identity Theft, Ministerial Backgroud Report: DSTI/CP (2007)/FINAL, 2008, diunduh dari <http://www.oecd.org/sti/40644196.pdf> $[10 / 7 / 2013]$

Oik Yusuf, 2013, Pengguna Internet Indonesia Bisa Tembus 82 Juta, 2012, <http://tekno. kompas.com/read/2012/12/13/10103065/2013.pengguna.internet.indonesia.bisa.tembu s.82.juta> [05/11/2013] 